\title{
LAISSEZ-FAIRE IN THE MALAY ARCHIPELAGO: A WESTERN CONCEPT?
}

\author{
Sivachandralingam Sundara Raja \\ Department of History, University of Malaya \\ (siva@um.edu.my)
}

\begin{abstract}
It is widely assumed that laissez-faire had its origins in the European context and that through colonization the countries of the East adopted the ideology. This might not be completely true for a distinctive brand of the same ideology had been prevalent in the Malay Archipelago long before the advent of western colonisation. In fact five trading zones, namely the Bay of Bengal, Straits of Malacca, the east coast of Malaya, the sea of Southern Vietnam, the Sulu Sea and the Java Sea, are known to have practiced a laissez-faire economy as far back as in the fifteenth century. This paper will trace the emergence of laissez faire ideas as embodied for example in free ports and trading zones prior to the arrival of western powers. It also shows how western powers used the existing free trade network to promote a colonial economy in the eighteenth and nineteenth centuries. Western powers in the late eighteenth and early nineteenth centuries were able to develop trade without territorial ambitions was due to the existence of a laissez-faire policy and the accommodative nature of the local rulers in this part of the world. The developments of Penang in the eighteenth century and Singapore in the nineteenth century are case studies to prove this argument.
\end{abstract}

Keywords: free trade, free port, free trade imperialism, Adam Smith, Malay Archipelago

\section{Introduction}

Laissez-Faire is a French word which means leave things be (Hill, 1980: 87). It was said to have originated from the request of a group of French traders who wanted trade activities not to be curtailed by the government. It was reported a group of traders met Jean-Baptoste Colbert, French Finance Minister (1661-1683). The minister thanked the traders for their contribution to the French economy and would like to know what he could do in return. Their answer were "Laissez-nous faire". Meaning leave us alone (Heilbroner \& Thurow, 1981: 23). Colbert was a strong proponent of free trade policy. He was against complex rules and regulation which controls industries in France during the time which was known 
as the Mercantilism System. One could imagine how he would have reacted to their wish.

\section{Laissez-Faire (How it was promoted in Europe)}

The word Laissez - Faire came to be used widely in the second half of $19^{\text {th }}$ century and early $20^{\text {th }}$ century. It was said the phrase "Laissez-Faire" was coined by the Physiocrat in France. It later became the watchword of the later English economists. Laissez-Faire/ Free Trade means free from restriction on trade. This restriction are two types. First the exclusive monopoly on trading companies; secondly the introduction of protective tariff or absolute prohibition on imports. In the early $17^{\text {th }}$ century the question of monopoly brought controversy and this led to the introduction of "Bill of Free Trade" and the term "Free Trader" which refers to those who went against monopoly. When high tariffs were imposed on foreign products, traders started to discuss about the need to free traders from such restrictions. This led to the origin of the term free trade which means free from protective tariffs and restriction. It could be concluded that the term free trade which is widely used today originated in the $17^{\text {th }}$ century (Thomas, 1963: 78).

\section{Laissez-Faire as Understood by Scholars and as was practised in the Straits Settlements}

Cook defines free trade as "Free exchange of commodities, unrestricted by the imposition of duties by government, except perhaps for revenue purposes" (Cook 1983: 123). Encyclopedia Britannica define free trade as ".. a policy by which a government does not discriminate against imports in favour of national products or interfere with exports in order to favour consumers in the home market. Free trade does not mean that a government abandons all control and taxation of import and export but only that this control and taxation are not used to protect the home producer against the foreign consumer (Encyclopedia Britannica, 1970: 850-851). In the case of the Straits Settlements the government did not allow or interfere in trade activities except to provide efficient administration facilities and a stable currency. In such a situation, individuals were free and different groups and communities specialised in fields in which they were efficient (Tate, 1979: 157). In the case of the Straits Settlements, when Penang and Singapore were developed as free ports, local traders still collected tax through the system of 'present', commission, and partnership in trade in their respective port (Tregonning 1959: 59). This matter is also mentioned in the Straits Settlements Record. "... to the invariable practice to all Malay ports, have been in the habit of receiving antarantaran, or complimentary present from the Nakhoda's of Junk and native vessels ..." (SSR (IOL) 10: 337-338). 


\section{Adam Smith and Imperialism of Free Trade}

The idea of free trade was further developed by Adam Smith in England with the founding of an institution known as School of Political Economy (Briggs \& Jordan 1964: 188). His idea influenced two other great economist, David Ricardo and Thomas Malthus. This three thinkers/economist felt government should not interfere in the affair of the economy and let the economy function naturally. It was believed by doing so the economy will function more effectively and bring maximum welfare to the people (Cook, 1983: 123). In brief it could be said Adam Smith wish the government to be a mere spectator and leave the economy to the rule of demand and supply.

The idea promoted by Adam Smith and his colleagues had great impact on the political economy of England. The scenario in its empire and the changes which was taking place has great impact on the development of free trade system. The free trade idea was also influenced by foreign factors like the Continental System introduced by Napoleon Bonaparte, impact of the British War with America between 1812-1816. Internal factors include impact of Industrial Revolution, the role of economist, pressure from radical groups, role of utilitarians and religious group and pressure from Manchester Merchants who demanded England to do away with Mercantilism and adopt the policy of free trade.

England was the first country to fight for the abolition of Mercantilism policy. It was latter followed by the French and other countries. The need for the local rulers in other parts of the world, to open up their economy to free trade in the East was obvious with many trading treaties signed to enable foreigners to trade freely. Such example were the British and Dutch treaty in 1824 (in Malaya); Bowring Treaty 1855 (in Thailand); Treaty of Nanking 1842 (in China) and many more. All this treaties created avenues/rooms for foreign power to trade freely and avoided military ambition especially in South East Asia. The free trade policy could be accepted by the locals because this was the kind of trade encouraged in the Malay Archipelago prior to the presence of western powers in the $16^{\text {th }}$ century. Therefore it was no surprise to see it accommodates well to the free trade policy promoted by the foreigners.

The assumption that laissez-faire was a policy created by the west was more obvious when political leaders associate it with religion. According to Sir John Bowring, the Manchester trader, "Jesus Christ is free trade and free trade is Jesus Christ (Hyam, 1976: 58). Certain statesman believe that as a Christian state, trade has to be free as free as air of heaven (Seaman, 1982: 300). It could not be denied that Christianity was used as a tool by the British to civilize the society. This was admitted by British Foreign Secretary, Lord Palmerston (1830-65). 
According to Palmerston,

Free trade was of quinstessential importance... Commerce was the best pioneer of civilization the dispensation of Providence. God meant man to be dependent on man: the world was made as it was so as to encourage the exchange of commodities, accompanied by the extension and diffusion of knowledge- by the interchange of mutual benefits engendering mutual kind feelings - multiplying and confirming friendly relations'. Commerce was intended to go forth freely, leading civilization with one hand, and peace with the other, to render mankind happier, wiser, better...(Hyam, 1976: 58).

Certain developments which were taking place in the East, particularly in India, China and Southeast Asia in the 19 ${ }^{\text {th }}$ century do confirm the boggy that laissezfaire was a policy introduced by the west. This was more evident with the dismantling of monopolistic trade system in the East. Only in 1813 the monopoly trade of East India Company with India was abolished and private traders were free to trade in India (Redford, 1934: 113). In 1833, the monopoly of EIC with China came to an end (Khoo \& Lo, 1977: 680). Many trading treaties which uphold laissez-faire was signed in the East. Such treaties were the Bowring Treaty (1855) between the English and the Siamese Government; the Nangking Treaty with China after the first Opium war in 1842 and many more.

In fact during the Opium War, the British felt the Chinese were uncivilized and unaware of the importance of free trade. To quote Sir Henry Pottinger,

... in our intercourse with China and her subjects, we are dealing with an empire and people who have no notion however small, of international law and rights. As far as the Peking was concerned the British were still barbarians on the seaboard (Khoo \& Lo, 1977: 680).

From the above discussion one could deduce that rapid changes which were taking place in Europe and the outer world do portray that laissez-faire is an European phenomena, particularly the British when many free trade treaties were signed with the local rulers outside Europe. Only when one look back a few hundred years back one could see that laissez-faire policy was practised in the East, particularly in South East Asia with a character of its own.

\section{Malay Archipelago Prior to the Presents of Western Powers}

G.Winsdor, in his article which was published in the Journal of the Indian Archipelago in 1850 clearly list out all the ports in the Malay Archipelago which 
practiced laissez- faire policy (Winsdor, 1850: 240-245). From the information provided it is obvious that the Malay Archipelago has practiced laissez- faire policy very long before the presents of western powers. The eastern laissez- faire policy was unique and has its own characteristic. If such a policy did not exist in this part of the world, foreigners would have used gunboat policy to achieve their ambition. This would have effected their treasury and Asia would have seen great deaths. The fact that most of the countries in Asia adopted indirect rule was very much related to the laissez-faire policy adopted prior to that. Intervention was done through negotiations and not by force. The fact that, free trade and free ports existed in the Malay Archipelago was brought to the fore by scholars like D.K. Bassett. According to him,

\begin{abstract}
A highly complex international commerce already existed in which, with minor exceptions, the English could participate freely. They were not denied access to the important traditional coastal entrepots, so long as they remained under indigenous governments" (Bassett, 1968: 86). ... the region from Pegu and Tenasserim-Mergui through certain Malay ports and Aceh to Ayudhya and Tongking constituted what might loosely be called the free trade zone of maritime South-East Asia (Bassett, 1989: 625).
\end{abstract}

Malay Archipelago already had trade links with the outside world before the modern age (Hanizah Idris, 1996:64). Local conditions suited the strategy of free trade and free ports which were used by the foreigners to develop the settlement in the Malay Archipelago. Before the arrival of the Europeans, the Spice Islands formed a well-structured regional trade network (Villiers, 1990: 83). A number of important ports emerged in the Malay Archipelago, like Pedir, Pasai, Sri Vijaya, Demak, Tuban, Makasar and Malacca (Kathirithamby-Wells \& Villiers, 1990: 83). The ports functioned as free ports and traded without restrictions (Hall, 1985a: 194-231). Beginning from the fourteenth century, five trade zones emerged in the Straits Settlements. The first trade zone was the Bay of Bengal which began at the Coromandel Coast, South India and included Sri Lanka, the Northern Malaysian Peninsula and the North and West Coasts of Sumatra. The North and West Coast of Sumatra became important in the years after 1300 due to the world's great demand for pepper. The entrepot port of Samudra Pasai on the east coast became important supplier of pepper for the traders from the East and West (Hall, 1985a: 225).

The second trade zone, the Straits of Malacca, became important in the fifteenth century due to political protection it received from China. After the 1430's the development of Malacca no longer depended on China's support but more on its trade and relations with java and the South East Asia regions. Malacca is a port 
of the fifteenth century which practiced free port policies. The free trade policy is seen from the shipping facilities provided for foreign and local traders; protection given to traders in the port, good judiciary system and a uniform monetary and measurement system. All these facilities enable trade to develop freely and rapidly. Its position as free port could be seen from the freedom given to foreign traders visiting its port and a fair tax system imposed on them. Local traders were taxed 3\% whereas foreign traders were taxed 6\% (Meilink-Roelofsz, 1969: 40-45). The Malacca government is also said to have had an advanced maritime code. Raffles considered the Malacca Code as the best which became the choice of many other states. The Malacca Law was founded in the era of Sultan Mahmud Shah (1424-1444) and it is a law enforced on ships, jongkong and boats. The contents of the law related to officials who handled boats, the collection of tax, punishment against individuals who were guilty on board the boat and those who disobeyed captain's order etc (Raffles Collection, Volume 11).

The third zone comprised the east coast of the Malay Peninsula and the sea of Southern Vietnam, the area bordering the Gulf of Siam. Ayudhya was a growing power in this zone. It was formed in the early fourteenth century and started to export rice to Malacca in the fifteenth century. It played the role as a trading centre with the Philippines and China (Hall, 1985a: 226).

The Sulu Sea represented the fourth trading zone. The areas which it comprised included the West Coast of Luzon, Mindoro, Cebu and Mindanao in the Philippines and the northern coast of Borneo. All these places functioned as trade links with China and the Spice Islands in South-East Asia. The Spice Islands were producers to agricultural products such as nutmeg, mace, cloves, and sandalwood which were sent through the Sulu Sea to China and Thailand in the north; Java and Malaccca in the West. The channel of Java Sea represented the fifth trade zone. It consisted of the Island Straits of Sunda, the island of Maluku, Banda, Timor, the West Coast of Borneo, Java and the west coast of Sumatra (Hall, 1985a: 226).

When the Europeans came to the Malay Archipelago they did not create new trade routes, in fact they made use of the old ones (Hall, 1985b: 85). All the ports which were located in these trade zones, such as Malacca, Aceh, Pasai, Bantam, Macassar, Ayudhya and other ports experienced a rapid progress in trade. The freedom in trade enabled the ports to attract traders from the East and West and functioned as a political, economic and social centre.

According to Raffles,

When the Europeans first frequented the Archipelago, the trade had long collected at certain established emporia, of these Achean, Malacca and Bantam were the principal. Macassar on Celebes, had also become an emporium of the more Eastern Commerce. ... the smooth seas of the Archipelago is readily conveyed to the most advantageous markets. 
Foreign traders in large vessels found it more to their interest to proceed to the emporia, where they might at once procure a full cargo. The foreign commerce was carried out with ease and safely and to manifest advantage of all parties (SFR Vol. 50: 25).

With the existence of a trading network in the Malay Archipelago and together with the elements of free trade and free port, it encouraged the British to develop free ports in the Malay Archipelago in the late eighteenth and early nineteenth century. The emergence of Penang and Singapore as free ports was based on these factors (Tate, 1979: 150).

\section{Laissez-Faire Ideas to Promote Colonial Economy in the $18^{\text {th }}$ and $19^{\text {th }}$ Century}

To prove how the western powers used the free trade network to promote its economic ambition, the port of Penang and Singapore in the Malay Peninsula will be taken as case study. The ability of Francis Light to acquire and develop Penang as a free port was very much contributed by its laissez- faire status it enjoyed before that. Penang has traded with many parts of the world and country traders had good relations with the Malay traders. Francis Light himself was a country trader.

Since England became involved in the Seven Years War (1756-1763) with certain European countries, English trade activity in the East, especially in the Straits Settlements, was performed by country traders. This group played an important role in promoting relationships with the Malay States. The official policy of the East India Company at that time was to have trade agreements with the local rulers, to establish trading posts at the main routes and to avoid the occupation of territories and political responsibility (Francis, 1969/70: 74).

James Scott, Francis Light and Thomas Forrest were among the individuals who successfully implemented the political objective of British Government. They had a cordial relationship with the Malay rulers. Only through such relationships the supply of the Malay Archipelago products, especially tin, for the Chinese and European markets was assured. This is no surprise because at the end of eighteenth century, the average yearly trade of a Malay state was between 150-200 thousand Spanish dollars (Bassett, 1980: 27).

From the middle of 1760 's, the increasing activity of the country traders in the Straits of Malacca became more obvious. In the first half of the century, not more than 10 English private traders stopped at Malacca every year. Towards the year 1769, this number increased to 26. Among the factors which led to the increased activity of the country traders was the increasing trade of the East India Company with China. Within ten years, the number rose. Many European ships were known to have stopped at Riau and other ports in the Straits of Malacca 
(Lewis, 1970: 117). Many of the company ships which brought cargo to China were ships brought by country traders to India from the ports of the Malay Archipelago (Lewis, 1970: 117).

The role of the country traders in the earlier stage is obvious at Riau. Riau was an important trading port in the Malay Archipelago after Malacca (SSR (IOL) Vol. 1: 71-72). It became a centre for the Bugis traders to gather trade from all other parts of the Malay Archilpelago. Many of the products brought to Riau by the Bugis traders were from Inderagiri and Jambi, whereas Palembang traders brought tin. In brief Riau traded with Java, Palembang, Bangka, Ujung Salang, Inderagiri, Jambi, Island of Moluccas, Borneo, Bali, Siam, Cambodia, Annam, Cochin-China and China. The products traded at Riau were collected by country traders to be exchanged in China.

Selangor, another state in the Malay Peninsular was also influenced by country traders. Here they had developed good relationships with the local rulers to the extent of being invited to become advisers (SSR (IOL) Vol 1: 68). When Sultan Ibrahim (1778-1826) from Selangor, with the help of Bendahara Abdul Majid from Pahang, attacked the Dutch fortification at Kuala Selangor, on $27^{\text {th }}$ June 1785, the fortification could not be captured and it was abandoned hurriedly. Sultan Ibrahim immediately asked for Francis Light's assistant from Penang to wave the British flag and requested for an appointment of a Resident in his state to enable him to trade freely with the Bugis (SSR (IOL) Vol. 3: 9).

Sultan Ibrahim made a special request for the appointment of Francis Light, James Scott or Thomas Forrest at Kuala Selangor. Francis Light in his letter to the Acting Governor General, John Macpherson, on February 1786 stressed that Sultan Ibrahim had valid reason to get British help. This based on the good treatment received by English traders since the era of Ibrahim's father.

The trading activity of country traders in Trengganu, another state in the Malay Peninsular was established before the East India Company occupied Penang. In April 1764, Sultan Mansur I (1764-1793) sent a letter requesting help from the Captain of the Panther ship which stopped by in Trengganu on its way to Manila and China. The Sultan requested for ammunition to deal with his enemies. The captain of the ship relayed the matter to Joseph Jackson, commander of the East India Company ship, Pitt which was on its way to Canton with a supply of tin. Jackson then reported his meetings with the ruler of Trengganu on his visits here on $14^{\text {th }}$ June, 1764. The Sultan was unhappy with the Dutch policy in Trengganu. According to Sultan, it is normal for European countries to have a bad notion of the Malays, but if they knew how bad the attitude of the Dutch was towards the Malays, they definitely would not behave like this (Francis, 1969/70: 74). 
... but if they [European countries] knew but one half of the cruelties the Dutch had been guilty of to the Malays [sic] they would not be blamed so much as he believed they generally are (Francis 1969/70: 7577).

The Sultan welcomed the British who were willing to send a ship to begin trade relations with all nations which has links with the Gulf of Siam, Cochin-China, Cambodia and Borneo. Jackson also reported after staying in Trengganu for almost two years that Britain could gather tin amounting to 30 thousand bahar every year at a low price. He also informed the East India Company that a settlement called Legore[sic] has three mines and produced at least 30 thousand bahar of tin each year. Jackson information clearly shows the importance of Trengganu in that century. This proven from the list of items available at a number of places in the Siam Gulf enclosed in his report (Khoo, 1974: 17-22).

Based on the relationship cultivated with the Malay rulers, Francis Light succeeded in influencing the Acting Governor - General of Bengal, John Macpherson, to occupy Penang and to develop it as a free port. In his letter to Macpherson, he explained Penang's potential. According to him, Penang could attract Bugis, Chinese and Malay traders, developing it further to a famous entreport port (SSR (IOL) Vol. 2: 436).

It cannot be denied that the country traders played a vital role in the Malay Archipelago between the seventeenth and eighteenth centuries. Through cordial relations cultivated with local rulers, they secured supplies from the Malay Archipelago for the benefit of the Chinese trade and made it easier for the implementation of free trade and free port policies in the Straits Settlements at the end of eighteenth and early nineteenth centuries. The emergence of Penang and Singapore as free ports met the need of country traders who wanted to attract local traders and to fight the Dutch monopoly (Bassett, 1989: 14).

It was no surprise that with just two years after Penang was opened, trade flourished, population increased and investors started to invest in the mainland. Traders started to move in big numbers to the port because they were happy with laissez-faire policy it adopted compared to the monopoly policy adopted by the Dutch. The similar effect was evident when Singapore was occupied in 1819 and it was declared as a free port. Traders from all over Asia and Malay Archipelago came in thousands to trade in Singapore. According to Raffles,

The occupation of the island of Singapore by the British, and the policy pursued by them ever since has caused a revolution of opinion throughout these islands; the state of trade has changed, and nearly the whole of the natives have thrown their resources into another channel (SCCR 1832). 
After Singapore was developed, it succeeded in attracting local traders especially the Bugis. Although at that time there were many Dutch ports but the duty imposed was high. According to Bastin, they definately would not have sailed hundreds of miles away from the main route if not for Singapore's free trade (Bastin \& Winks, 1966: 155; Hanizah Idris, 1997: 67). The amount of goods brought from Borneo, Sulawesi and Bali between the years 1828-1829, is estimated to be 1,040,761 sicca rupi (SC: 1830). The liberal policy also succeeded in attracting the Chinese who were not happy with restriction policies practiced by the Dutch and Spanish (JIA Vol 9, 1855: 109-110). Many local rulers thanked Raffles for occupying Singapore. Malay ambassadors and rulers came to Singapore to thank Raffles personally. According to Raffles Report,

From Tringano I found in the harbour one of Sultans vessel which his Highness has dispatches with Rui[sic] and other supplies immediately on having our establishment. This state is one of the most important of the Eastern side of the Peninsula and has hithertho escaped the influence of the Dutch; the Sultan and principal chiefs availed themselves of this occasion to express their anxiety and desire to cultivate a more intimate and closer connection with our Government. The same anciety has been expressed on the part of the chief of Kalantan [sic] a rising and flourishing state lying between Tringano and Siam The people of these countries seem to consider the British alliance and protection essential to their interest and prosperity (SFR 47: 807).

In short, the policy of free trade and development of free ports in the Malay Archipelago attracted local traders with the products of the Malay Archipelago to the port of Penang and Singapore (Shaharil Talib, 1995:7). It also managed to gather products of the Malay Archipelago, especially tin which was exported from Cromwell to Canton, almost half originated from British colonies.

British were able to attract investors who were not only keen in trading but also venturing into commercial crops like pepper, nutmeg, clove, pineapple and coffee. Investors started to move into mainland Malay Peninsula. Commercial crops like pepper and nutmeg was introduced in Johore and later in other states. Slowly commercial economy was promoted in the Malay states in the second half of $19^{\text {th }}$ century. It was commercial crops which helped in the forming of an agricultural policy to support rubber plantation in the early $20^{\text {th }}$ century. 


\section{Conclusion}

From the discussion one could see that the idea of laissez- faire as understood by Adam Smith has long been practiced in the East prior to the $15^{\text {th }}$ century. The later was unique with its own characteristic. When one speaks of laissez-faire, Adam Smith is the individual comes to our mind. This could be because he was the one who had made it clear in writing. Anyway when one look closely at the Malacca Code (Hukum Kanun Melaka) of the $15^{\text {th }}$ century, the contents do speak of laissezfaire ideas but there is no single promoter. Through this paper it is hoped a balance picture brought to light that laissez-faire policy is an Eastern phenomena and it has been practiced in this part of the world very much earlier prior to the presents of western powers. The fact that European powers did not conquer many of the countries in South East Asia in the early 19th century through gun boat policy is very much due to its laissez-faire policy imbedded in its economy.

\section{Endnotes}

${ }^{1}$ Country trader were also known as private traders. At first they were traders of the East India Company. However, when civil war erupted in England in 1657, a new charter was given by Oliver Cornwell to the East India Company traders and these traders were ordered to withdraw from Asian waters. The orders were not adhered to by many of the traders and this prompted King Charles II to order that those who went against his order were to be arrested and brought back to England. His order were not effective and the traders were still trading in Asia. These were the traders who are known as country traders. The trading activities of this group were between India, the Malay Archipelago and China. Among the country traders who were famous in the 1770's and 1780's are Francis Light, James Scott and Thomas Forrest (Bassett, 1961; Bassett, 1961).

2 The advantage of the port of Riau is also mentioned in the Straits Settlements Record. It is estimated that the value of Riau's trade for a year was two million Spanish dollars.

\section{References}

Bassett, D.K. (1961). The British country trader and sea captain in Southeast Asia in the 17th and 18th centuries. Journal of the Historical Society, 1(2), 9-14

Bassett, D.K. (1961). Thomas Forrest, an eighteenth century mariner. Journal of the Malayan Branch of the Royal Asiatic Society, 34(2), 106-122

Bassett, D.K. (1968). Early English trade and settlements in Asia 1602-1690. University of Hull: Centre for Southeast Asian Studies.

Bassett, D.K. (1980). British attitudes to indigenous states in Southeast Asia in the nineteenth century. University of Hull: Centre of South East Asian Studies.

Bassett, D.K. (1989). British "country" trade and local trade network in the Thai and Malay States circa 1680-1770. Modern Asian Studies, 23(4). 
Bastin, J., \& Winks, R.W. (Compilers). (1966). British in Malaya, Malaysia, selected readings. Kuala Lumpur.

Briggs, M., \& Jordan P. (1964). Economic history of England. London: University Tutorial Press.

Cook, C. (1983). Dictionary of historical terms, a guide to names and events of over 1,000 years of world history. New York: The Macmillan Press Ltd.

Encyclopaedia Britannica. 1970. Chicago: William Benton.

Francis. M. (1969/70). Captain Jackson's report on Trengganu 1764. Journal of the Historical Society, 8. University of Malaya.

Khoo, G., \& Lo, D. (1977). Asian transformation, a history of South-East, South and East Asia. Kuala Lumpur: Heinemann Educational Books Ltd.

Hall, K.R. (1985a.) Maritime trade and state development in early South East Asia. Honolulu: University of Hawaii Press.

Hall, K.R. (1985b). The opening of the Malay world to European trade in the sixteenth century. Journal of the Malaysian Branch of the Royal Asiatic Society, $58,(2)$.

Hanizah Idris. (1997). Pulau Singapura 1819-1930-peranan pulau-pulau lain yang terpinggir didalam sejarahnya. Journal of Southeast Asian Studies (JATI), 3.

Hanizah Idris. (1996). The maritime nexus. Journal of Southeast Asian Studies (JATI), 2.

Heilbroner, R.L., \& Thurow, L.C. (1981). The economic problem. New Jersey: Prentice-Hall Inc.

Hill, G.P. (1980). British economic and social history 1700-1975. London: Pitman Press.

Hyam, R. (1976). Britain's imperial century 1815-1914, a study of empire and expansion. London: Batsford.

Journal of Indian Archipelago (JIA) 1855: 9. Notes on the Chinese in the Straits.

Kathirithamby-Wells., \&Villiers, J. (ed.). (1990). The South East Asian port and polity, rise and demise. Singapore: Oxford University Press.

Khoo, K. K. (1974). Kuala Terengganu: International Trading Centre. In Malaysia in History. Kuala Lumpur: Persatuan Sejarah Malaysia.

Lewis, D. (1970). The growth of the country trade to the Straits of Malacca, 17601777. Journal of the Malaysian Branch of the Royal Asiatic Society, 43(2).

Meilink-Roelofsz, M.A. (1969). Asian trade and European influence in the Indonesian archipelago between 1500 and about 1630. Hague: Martinus Nijhoff.

Raffles Collection (RF). Volume 11: 195-209.

Redford, A. (1934). Manchester merchants and foreign trade 1794-1858. Manchester: Manchester University Press.

Seaman, L.C.B. (1982). A new history of England 410-1975. London: Macmillan Publisher Ltd. 
Shaharil Talib. (1995). Singapore (1824-1958): This is my island in the sun. Journal of Southeast Asian Studies (JATI), 1.

Singapore Chronicle. 4 Jan. 1827 - 30 Sept. 1837 (SC).

Singapore Chronicle and Commercial Register. 1835-1837 (SCCR).

Straits Settlements Records (Indian Office Library) (SSR-IOL). Vol. 1:1769-1795

Straits Settlements Records (Indian Office Library) (SSR-IOL). Vol. 2: 2 Mar. 1786 Dec, 1787

Straits Settlements Records (Indian Office Library) (SSR-IOL). Vol. 3: 25 Jan. 1788 28 Dec. 1791

Straits Settlements Records (Indian Office Library) (SSR-IOL). Vol: 10: 1808 - 1825

Sumatra Factory Records (SFR) Vol.50:Letters from Fort Marlborough, Bencoolen, 25 Dec. 1819-1 Feb. 1821

Sumatra Factory Records (SFR) Vol. 47:Fort Marlborough Letters to E.I.C

Tate, D.J.M. (1979). The making of modern South East Asia. Volume II. The Western impact: Economic and social change. Kuala Lumpur: Oxford University Press.

Thomas, P.J. (1963). Mercantilism and the East India trade. London: Franck Cass and Co., Ltd.

Tregonning, K. G. (1959). Penang and the China trade. In Malaya in History, 5(1), 812.

Villiers, J. (1990). The cash-crop economy and state formation in the spice islands in the fifteenth and sixteenth centuries. In Kathirithamby - Wells \& J. Villiers, (ed.), The South East Asian port and policy, rise and demise. Singapore: Oxford University Press.

Walker, J. (1981). British economic and social history, 1700-1980. London: Fletcher and Sons Ltd.

Williams, J.B. (1973). British commercial policy and Great Briatin's trade expansion 1750-1850. London: Oxford University Press.

Winsdor, G. (1850). The trading ports of the Indian Archipelago. Journal of the Indian Archipelago (JIA), 4. 